\title{
Quality circles as a means for achieving worker satisfaction - or just a healthy managerial climate? A South African sample
}

\author{
Robert J. Robinson \\ Graduate School of Business Administration, Harvard University, Soldiers Field, Boston, Massachusetles 02163 \\ United States of America
}

Received February 1993, accepted August 1993

\begin{abstract}
There is very little evidence that participative work programmes such as quality circles (QCs) improve the subjective experience of workers, either on the job, or in their lives generally. Part of the reason for such limited success is offered by literature suggesting that interventions such as QCs should reflect a general organizational philosophy of participation. rather than being the means to enforce organizational change. This study was undertaken in a large South African electrical utility, and consisted of $187 \mathrm{QC}$ members and 63 non-QC members. Managerial climate was measured using a short form of Likert's organizational climate questionnaire, while worker satisfaction was measured using five different measures. Results revealed QC members scored higher on life satisfaction, self-esteem and purpose-in-life than non-QC members. Significant positive correlation was found between managerial climate and satisfaction indices. Regression analysis indicated that managerial climate variables accounted for the major share of the total variance in satisfaction indices, while participation in the QC programme accounted for relatively little: the implication is that $Q C$ participation may bring about increased worker satisfaction, but a critical pretequisite appears to be a suitably participative climate in the organization.

Daar bestaan baie min bewyse dat deelnemende bestuursprogramme, soos gehaltekringe, werknemers se subjektiewe ervaringe by die werk of in hul gewone lewens verbeter. Die beperkte sukses van sulke programme word in die literatuur deels daaraan toegeskryf dat ingrepe soos gehaltekringe 'n algemene organisatoriese filosofie van deelname behoort te reflekteer, eerder as om die instrument te wees wat organisatoriese verandering afdwing. Dié studie is gedoen by ' $n$ groot Suid-Afrikaanse elcktrisiteitsvoorsiener en het 187 gehaltekringlede en 63 nie-lede ingesluit. Die bestuurs klimaal is gemeet deur 'n verkorte formaat van Likert se organisasie-klimaatsvraelys te gebruik. Werknemertevredenheid is deur middel van vyf verskillende metings geëvalueer. Die resultate toon dat gehaltekringlede hoër tellings behaal ten opsigte van lewenstevredenheid en selfbeeld as nie-gehaltekringlede. Prakties betekenisvolle positiewe korrelasies is vasgestel tussen bestuursklimaat en tevredenheidsindekse. Regressie-ontledings dui daarop dat bestuursklimaatveranderlikes veral verantwoordelik is vir die variasie in tevredenheidsindekse, terwyl declname aan die gehaltekringprogram vir baie min variasie verantwoordelik was. Die implikasie is dat gehaltekringprogramme mag lei tot verhoogde werknemertevredenheid maar dat die belangrikste voorvereiste 'n toepaslike deelnemende klimaat in die onderneming blyk te wees.
\end{abstract}

\section{Introduction}

The question of worker participation and the role of employee satisfaction in increased productivity is a recurrent one both in business and psychological literature. Decades of research have given us certain well-grounded conclusions: a. technology, particularly automation and the productionline system, is often a significant contributor to alienation (e.g. Shepard, 1970; Cotgrove, 1972; Susman, 1972); b. jobs can be redesigned to counter alienation (e.g. Scheips, 1972; Walton, 1972; Frank, 1973); and c. worker participation is one of the best ways to achieve this countering effect (e.g. Fuller \& Bonjean, 1970; Denhardt, 1971; Strauss, 1974).

Such studies gave legitimacy to the 'job redesign' movement, a broad-based and eclectic attempt to find alternative work forms which would eliminate alienation and maximize productivity and participation. Fine summaries of this work is available in such reviews as Hackman \& Lee (1979), and Guzzo (1983). Interventions fall into categories such as sociotechnical systems, job enrichment, job enlargement, work schedules, environmental fit, ergonomic design, automation, robotics, and computerization. The only common basis for inclusion in the category of job redesign is an underlying philosophy aiming at

'the design of effective and satisfying jobs, which meet both the organization's needs for effectively achieving its goals through the use of its human resources and the individual's needs, expectations and goals' (Davis \& Wacker, 1982: 2.5.1).

\section{The effectiveness of participative work designs: an ongoing debate}

The effectiveness of participative work designs has been the topic of controversy for decades now, with little sign of resolution. Recently, the debate has again become particularly acrimonious. Although researchers such as Clemmer \& McNcil (1988) and Larson (1989) continue to indicate benefits from participation, most arguments center around what is being measured, and what would constitute an effective intervention. In analyzing the results from a number of US military bases, Steel \& Mento (1987) found litte link between participation and productivity. Wagner \& Gooding (1987) criticize inconsistent research methodologies within this area, and suggest that researchers are being swayed by societal trends. Locke, Schweiger \& Latham (1986) found that participation is just as likely to lower productivity as it is to raise it, if employees do not have expertise to bring to the decision-making process. Cotton, Vollrath \& Froggatt (1988) argue that 'participation' is too broad a term, and attempt to classify interventions into various types, citing markedly different outcomes for the different kinds of techniques, thus explaining the wildly inconsistent and unreliable results in the literature.

Critiquing this study, Leana, Locke \& Schweiger (1990) suggest that the findings of Cotton, et al. were largely the result of their own classification system, and showed that by classifying studies differently, a considerably different 
outcome could be obtained. In their rebuttal, Cotton, Vollrath, Legnick-Hall \& Froggatt (1990) refuse to acknowledge methodological problems, and assert that the basic success of participative work designs depends on the nature and form of the intervention.

This debate is obviously complex and dynamic: it is not intended to offer a solution here. However, by way of considering a specific intervention rather than making generalizations, and as an introduction to the present study, the issue of quality circles is offered.

\section{Origins of quality circles}

The history of quality circles (QCs) begins in 1948, when in an attempt to rebuild the Japanese economy after the Second World War, quality control was introduced from the United States, via world-experts, Demming and Juran. Despite its lack of popularity in the USA, between 1948 and 1960 quality control became an extremely popular and well-researched subjoct in Japanese industry, and the majority of workers were exposed to the concept. As part of involving all levels of workers, the first $Q$ Cs were developed and stanted in 1962 at IBM, but were not successful in the USA and had more or less died out at the time they became popular in Japan. There a national QC body was formed in 1964, and soon had chapters throughout Japan. The growth of QCs was explosive, and by 1984 there were over 180.000 registered circles in Japan. A similar movement has been stanted in both Taiwan and South Korea with great success and QCs have 'come home' to the USA. Internationally, QCs are additionally currently to be found in such diverse countries as Australia, Belgium, Brazil, Denmark, Egypt, Israel, Italy, Korea, much of Latin America, Malaysia, the Netherlands, South Africa, Taiwan, Thailarid, and the United Kingdom. The impetus for particularly the Western interest in QCs (and Japanese management) came from the spectacular success of Japanese companies in the West's traditional markets.

\section{Success of quality circles in the West}

With the success of Japanese industry, Western nations have eagerly taken up the techniques of Japanese management, including the quality circle which has been implemented in an impressive range of areas. Apart from the production environments which they were originally designed for, quality circles have been put to work in such white-collar areas as universities, accounting firms, banks, and the military. A question which arises perennially is that of the adaptability of such techniques to Western societics. A typical argument is that of Yamamoto (1986) who offers an almost totally cultural explanation, citing psychological factors stemming from feudal Japan for the present form and success of industry there. By way of contrast, Garvin suggests

'... such arguments are easily overstated. They border on cultural determinism, confusing habits or tasks that support a particular end with more complete explanations' (1988: 198).

In Japan, QCs are judged to be a huge success by virtue of their longevity and the growth of the Japanese economy. In comparing the progress of countries which have used QCs with those which have not, Bocker \& Overgaard (1982) are unequivocal in their praise for the posituve effect of QCs on national productivity. In the USA. Miller (1984) found that 63\% of all respondents in a survey felt that their $Q C$ program was 'moderately' 10 'extremcly' successful, with only 6\% reporting 'failures' or 'poor' results. Sherwood. Guerrier \& Dale (1985) found that most firms express satisfaction with the usefulness of the $Q C$ concept. Nevertheless. it hardly seems an appropriate or scienufic form of measurement to ask managers (who in many instances, have been responsible for the implementation of cosuy programs), whether or not they believe the programs work. While financial figures seem to be plucked out of thin air - 'Lockheed claims to have saved 2.844 .000 dollars with only 15 quality circles operating in the first two years' (Wayne, Griffin \& Bateman, 1986: 80) - it is the effect on the panicipants (i.e. auiudes, values, and motivation) which is more difficult to measure.

In Britain, Cox \& Dale (1985) found tha $83 \%$ of respondents (QC members) felt that QCs had provided them with real benefits. Marks, Hackeu, Mirvis \& Grady (1986) reported that QC members showed enhanced quality of work life perceptions relative to non-members. Rafacli (1985) found that QC members had a significantly higher perception of their own influence and job variety than nonQC members, while Elvins (1985) found that QC membership was associated with a higher degree of perceived power or influence. In South Africa, Daniel \& Huss (1986) concluded that quality circles are a positive influence for political change, and Nicholls (1985) found significanuly improved employee perceptions of management and better employ $\propto$-management relations after a participative QC-type intervention. The problem with many of these studies is the lack of a real control group, given the voluntary nature of QCs, and a possible halo effect when the measures are linked to QC participation.

Imperfect though these data are, evidence suggests that QCs are associated with a positive effect on productivity and quality, and on workcrs perceptions of their subjective working conditions, at least as far as their ability to influence those conditions is involvad. QCs are also scen to be a positive force for solving problems, and in enhancing communications. On a national level however, it is hard to escape the conclusion of Beardsley (1987), that like many other participative programs in recent history, QCs have not been set measurable goals, and this inability to assess their results threatens their future existence. A critical question must be, do QCs actually contribute anything more to organizations and their employees than halo (Hawthome) effects? This question is especially troubling in the light of recent studies. Thus Barrick \& Alcxander (1987) found that reported success of QC programs was due to the unique characteristics of voluntary participants. In tracking $\mathbf{Q C}$ participants for a threc-ycar period (Griffin, 1988), measuring attitudes, behaviour, and effectiveness, initial improvements were found, but were subsequently followed by a retum to previous levels. Similarly, Lawler \& Mohrman (1987) cite a 'honeymoon' effect with QCs. Stcel \& Lloyd (1988) found some support for an improved sense of competence and trust, but only marginal suppor for $Q C$ effectiveness. Summarizing the findings, Stecl \& Shane (1986) rightly conclude that the characteristics of 
organizations which may best benefit from $Q C$ interventions are still poorly understood, and with this in mind there must be some question as to the desirability of QCs in organizational contexts.

\section{Critical success and fallure criterla for circle pro- grams}

As QC programs got underway in the West, painful experiences with failed programs showed that there were certain things which should or should not be done if QCs were to be successful. Dale \& Hayward (e.g. 1984: 12) have identified the main causes for circle failure. One of the most significant regards management style: '...in a climate where management is too narrow-minded and autocratic, quality circles are unlikely to survive'. In a similar vein, Ingle (1982) and Tang, Tollison, \& Whiteside (1989) suggest that poor middle-management support is a prime indicator that a QC program will be in trouble if implemented. Steel, Mento, Dilla, Ovalle, \& Lloyd (1985) found that one of several factors distinguishing a successful from an unsuccessful $Q C$ program was management support, and in another study (Steel, Mento, \& Reha, 1985) noted improved attitude and morale, but only if management support was real and tangible. Castorina \& Wood (1988) discovered that in Fortune 500 companies, QCs succeeded to the extent that they did not come into opposition with the existing bureaucracy, while Drago (1988) has noted that one of the factors which enhanced QC survival is degree of participative management. In a meta-analysis of participative programs, Miller \& Monge (1986) found reliable links between participation and worker satisfaction, as well as the constraining role of organizational factors. Generally, management support and commitment to a participative management climate has emerged as probably the major success predictor of $\mathrm{QC}$ activities.

\section{Quality circles and worker satisfaction}

The review of the literature thusfar has revealed that the purpose of job redesign was primarily to enhance productivity by encouraging participation and increasing worker satisfaction. While it may be somewhat grandiose and pretentious to assume that any measurable personality 'development' will go on in adults exposed to a QC program, a more modest and attainable objective might be to increase worker satisfaction, and thereby reduce alienation.

Although some interesting data conceming productivity improvements have been reviewed here, the field remains somewhat devoid of evidence linking participation with worker satisfaction. The purpose of the present study is to attempt to assess the effect of QC participation on employee satisfaction, and to pay particular attention to the critical role of the organizational, or managerial climate.

\section{Overview}

A matched group of QC members and non-members was used. Subjects were asked to rate themselves on five different measures, namely, life satisfaction, self-esteem, powerlessness, locus-of-control, and purpose-in-life. They also rated the organization on its management style, both 'now' and for 12 months previously on a questionnaire which was designed for this study, and which measured five different aspects of managerial style. The effect of managerial climate and $Q C$ participation on the satisfaction indices was assessed.

\section{Method}

\section{Subjects}

Altogether 300 questionnaires were distributed. Completed questionnaires from $187 \mathrm{QC}$ members and 63 non-QC members were obtained, for an overall response rate of $83.3 \%$. Of these, 168 of the QC group and 48 of the non-QC group had been in the company 12 months previously, and were thus able to rate the managerial climate both at the present time and 12 months previously. There were 103 and 37 men in the two respective groups, the balance being women. 192 subjects were Afrikaans-speaking South Africans, and 139 English-speaking. Post-hoc analysis revealed no differences between men and women, or Afrikaans and English speakers on any measures (all $p$ 's $>$. 05). All subjects' jobs were categorized as semi-skilled, artisan-assistant, or clerical.

\section{Measuring instruments}

\section{Managerial climate}

A number of instruments have been developed over the years to measure the concept of the managerial style or climate. The progenitor and most successful of all these measures is the Likert Organizational Climate Questionnaire (Likert, 1967). This 51-item questionnaire scores responses on a unidimensional continuum ranging from 1.00 to 4.00 . Each station on the continuum is identified with a particular management style. ( $1=$ exploitative autocratic, $2=$ benevolent autocratic, 3 = participative, 4 = laissez faire). Subjects rate the organization 'now' (i.e. 'at the present time'), and as they remember it 12 months previously.

The correlation table of all items provided by Likert (1967: 194-195) points out 14 critical items divided into five basic factors. These five factors are:

1. trust and involvement, which addresses the issue of the relationship and trust between subordinates and superiors;

2. motivators, which relates to the way in which management attempts to motivate the employees;

3. communications, which looks at various aspects of organizational communication such as its effectiveness, direction, and clarity;

4. decision making, which examines the availability and utilization of information available in the organization when decisions are taken; and

5. control data, which questions the use to which performance data (costs, production reports, etc.) are put.

The sum of the five factors provides an overall managerial climate score.

\section{Worker satisfaction, control and purpose}

It was decided to broadly measure the notion of worker satisfaction, and to incorporate measures of general life satisfaction. Five well-known measures were employed, representing both relevant attitude and personality variables, 
Table 2 Satisfaction variables, mean scores

\begin{tabular}{lccc}
\hline $\begin{array}{l}\text { Salisfaction } \\
\text { variable }\end{array}$ & $\begin{array}{c}\text { non- } Q C \text { group } Q C \text { group } \\
(\mathrm{N}=43)\end{array}$ & Difference \\
& $(\mathrm{N}=158)$ & \\
\hline Life satisfaction & 28.53 & 31.96 & $-3.42^{*}$ \\
Self-esteem & 31.09 & 33.69 & $-2.60^{*}$ \\
Powerlessness & 20.31 & 20.42 & -0.11 \\
L.O.C. & 22.88 & 22.96 & -0.08 \\
P.I.L. & 28.82 & 30.22 & $-1.4^{*}$ \\
\hline p $<.05$ & & & \\
\hline
\end{tabular}
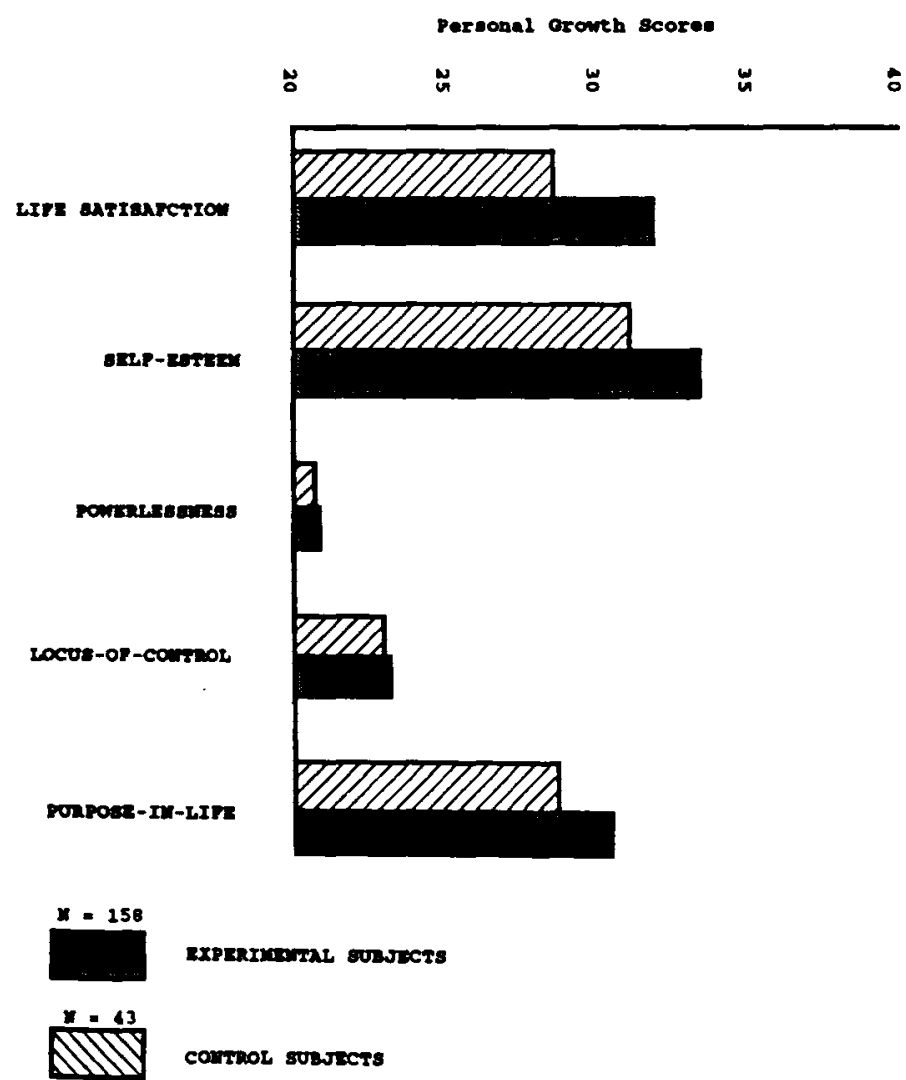

Figure 1 Satisfaction scores for $Q C$ and non- $Q C$ members
Table 3 Satisfaction correlations with managerial climate

\begin{tabular}{lll}
\hline Variable & $\begin{array}{c}\text { Non-QC group } \\
(\mathrm{N}=55) \\
\mathrm{R}\end{array}$ & $\begin{array}{c}\text { QC group } \\
(\mathrm{N}=171) \\
\mathrm{R}\end{array}$ \\
\hline Life satisfaction & $.245^{*}$ & $.299^{* *}$ \\
Self-esteem & -.129 & $.289^{* *}$ \\
Powerlessness & .177 & $.258^{* *}$ \\
L.O.C. & $.375^{* *}$ & $.363^{* *}$ \\
P.I.L. & $.254^{*}$ & $.411^{* *}$ \\
\hline p $<.05$ & & \\
$* \mathrm{p}<.01$ & & \\
\hline
\end{tabular}

scored significantly higher on life satisfaction, self-esteem and purpose-in-life than did the non-QC members $(p<.05)$. For all other worker satisfaction variables, there was no significant difference between the two groups (see Table 2 and Figure 1).

In correlating the independent variables and dependent variables in both groups, several positive significant relationships were obtained. Briefly, for the non-QC group managerial climate was significantly correlated with life satisfaction, locus-of-control, and purpose-in-life. In the QC group, significant positive correlations were found between managerial climate and all five worker satisfaction indices. These results are shown in Table 3.

Finally, a multiple stepwise regression analysis was performed to test the following basic model: (this is the general model, not a specific equation): Satisfaction $=Q C$ participation + Communications + Leadership + Motivators + Decision making + Control data $+Q C$ membership. ${ }^{5}$ The results show that for all worker satisfaction indices, at least one managerial climate variable accounts for a significant portion of the variance, while $Q C$ participation only accounts for an additionally significant fraction of the variance in the case of life satisfaction and self-esteem, supporting the results of the T-tests reported above. These results are summarized in Table 4.

Table 4 Regression - total amount of variance explained $\left(R^{2}\right)$

\begin{tabular}{|c|c|c|c|c|c|c|c|c|c|}
\hline \multirow{3}{*}{$\begin{array}{l}\text { Predictors } \\
\alpha C \text { participation }\end{array}$} & \multicolumn{9}{|c|}{ Satisfaction variables $(\mathrm{N}=216)$} \\
\hline & \multicolumn{2}{|c|}{$\begin{array}{c}\text { Life } \\
\text { satisfaction }\end{array}$} & \multicolumn{2}{|c|}{$\begin{array}{c}\text { Self- } \\
\text { esteem }\end{array}$} & \multicolumn{2}{|c|}{$\begin{array}{l}\text { Power- } \\
\text { lessness }\end{array}$} & \multicolumn{2}{|c|}{$\begin{array}{l}\text { Locus-of } \\
\text { control }\end{array}$} & $\begin{array}{l}\text { Purpose- } \\
\text { in-life }\end{array}$ \\
\hline & .02 & $(.16)$ & .02 & $(.11)$ & $*$ & $(*)$ & * & $(*)$ & $\left(^{*}\right)$ \\
\hline Communication & .13 & (.13) & .08 & $(.08)$ & $*$ & (.05) & .03 & (.13) & (.21) \\
\hline Trust \& involv. & $*$ & $(.09)$ & .06 & $(.05)$ & $*$ & $(.06)$ & $*$ & $(.15)$ & $(*)$ \\
\hline Motivators & * & $(.06)$ & $*$ & $(.03)$ & * & $(.03)$ & .11 & (.11) & $(.10)$ \\
\hline Decision making & * & $(.05)$ & * & $(*)$ & .07 & $(.07)$ & $*$ & $(.08)$ & $(.08)$ \\
\hline Control daca & $*$ & $(*)$ & * & $(*)$ & $*$ & $(*)$ & * & $(*)$ & $(*)$ \\
\hline \multicolumn{10}{|c|}{$\begin{array}{l}\text { less than } 0.01(1 \%) \text { of variance explained. Number in parenthesis indicates the total amoun } \\
\text { of variance which that variable explains, if all other variables were excluded from the ana- } \\
\text { lysis. The number outside the parenthesis is the additional or unique amount of variance ex } \\
\text { plained by that variable, and not shared with any other variable. }\end{array}$} \\
\hline
\end{tabular}




\section{Discussion}

Hypothesis 1

Worker satisfaction will be greater amongst $Q C$ members than non-QC members. This hypothesis appears to have been partially supported, as illustrated in Table 2 and Figure 1. The QC members showed significantly higher life satisfaction and self-esteem than the non- $Q C$ group, a finding consistent with the idea that exposure to $Q C$ activities over time can enhance self-regard due to an improved sense of competence. In addition, as shown in Table 2, the other (non-significant) mean differences tendad in the expected direction. $Q C$ members thus express more subjective enjoyment of life in general, and are more positive in their own self-evaluations, than is the case for non- $Q C$ members.

Hypothesis 1 is thus partially supported. That participative programs such as QCs do not enhance the other dimensions, especially measures such as locus-of-control which is a core personality construct, is disappointing, but not that surprising. According to these results, QCs do not impact more global questions such as making the workers feel more in control of their environment or life circumstances. In general therefore, it seems that $Q C$ membership is positively related to some, but definitely not all, of the variables used here. Individual, social, and environmental factors also play an extremely powerful moderating role in this relationship.

\section{Hypothesis 2}

In both $Q C$ and non- $Q C$ members, worker satisfaction will correlate positively with managerial climate. The results shown in Table 3 support this hypothesis, particularly in the case of quality circle members. Of all managerial climate indices, communications emerged as most consistently positively correlated to worker satisfaction. The regression analysis (Table 4) reveals that all five of the worker satisfaction variables are largely explained by managerial climate variables, in particular communications in the cases of life satisfaction, self-esteem, locus-of-control, and purpose-in-life. This is understandable, since the purpose of participation is largely to achieve personal growth by improving communications between workers and management, and by encouraging workers to come forward with their own views and suggestions. The results of the stepwise regression shows that there is an interaction between climate, QCs, and worker satisfaction. However, managerial climate variables account for a greater proportion of the variance in worker satisfaction scores than does participation in a $Q C$ program alone. Thus Hypotheses 2 has been supported.

Together with the discussion on Hypothesis 1, it seems that the actual managerial climate in the organization, particularly the communication style, rather than the presence of programs such as QCs, is a vital determining factor in encouraging employee satisfaction, self-estcem, and a sense of control and purpose. This result is consistent with the literature already reviewed, which pointed out the importance of real managerial commitment, bchaviourally and not thetorically, in the success of participative systems. QCs may thus be more a result than a cause of the sort of environment where employce satisfaction and growth is more likely to occur.
It was noved that on all managerial climate indices both groups reponted a significanlly more participative climaxe than for 12 months previously. As discussed, this phenomenon is most likely due to the 'halo' effoct, with a strong tendency loward the socially desirable response of indicating an improved climate compared to the previous year. However, a more interesting (but speculative) possibility also exists. If programs such as QCs have any value, it may be that they provide tangible evidence of managerial commitment to a more participative work environment, and thus send ripples throughout the organization, speeding up the process of achieving a more democratic managerial climates and thus bringing about the desired change in more individuals than those physically involved with QCs. The fact that the non-QC members were all drawn from corporate divisions where $Q C s$ were actually operating means that these respondents had all been 'rubbing shoulders' with $Q C$ members for the past several months. It is possible that management style changed in these sections to accommodate the requirements of QCs or in response to the increased maturity of the QC members, and that this changed style was applied equally to non-QC members as employees in the same section. $\mathrm{lt}$ is thus possible that $Q C$ members and non- $Q C$ members in the same section will both experience increased satisfaction.

This study thus confirms the tendency reponed in the literature towards more positive worker attitudes, perception of management style, and worker satisfaction, in the general area where a quality circle program has been in operation.

Regarding managerial climate and management style, Gelfand has found that while

'...the grouping of people into problem-solving units ... will result in an increase in human creativity ... the developmental strategy which determines this increase, however, is linked to the prevailing climate' (1975: 111).

This conclusion is echoed by Biesheuvel (1984: 125): '...the successful operation of QCs is dependent on a truly cooperative management climate throughout the enterprise', and Gibson, who notes that

'...quality circles are people with points of view about becoming involved in a paricipative problem-solving process. These viewpoints can make or break the process' (1982: 5).

Barrick \& Alexander (1987) reviewed the success and failure of QC programs in the USA, and reported that failure was most consistent and complcte in the military, a finding consistent with the theme of this article, namely that participative programs do not flourish in an autocratic environment. These results have important implications for the effective training of management in the coming years. Drago states that participative programs tend to come and go in cycles, but that QCs are more broad-based than any of the earlier systems, hence

'...the future of the circles movement will probably depend more than anything else upon managerial attitudes and commitment to participation' (1985: 16).

This study has provided an interesting confirmation to what insightful managers have known for many years actions spcak far louder than words. Workers can achieve greater satisfaction in the workplace, and productivity can 
be increased through participative work systems, but management commitment must be there in the tangible form of a participative supervisory style. A great need exists to make management competent in implementing and operating such a style, and to sell the idea that managers alone cannot carry the productivity burden of organizations. Involving workers in decision-making should not imply abdication by management; it is rather part of a basic restructuring of the way businesses are run.

\section{Notes}

1. This high response rate was made possible by the fine cooperation of the facilitators.

2. Locus-of-control is traditionally thought of as a personality dimension. It was included because it seemed an appropriate global measure.

3. For social scientists concemed with facilitating the transition from the apartheid system in South Africa, participative work programs offer one possible avenue whereby a disenfranchized segment of the population is afforded an avenue of expression. Further, such interventions begin to acculturate employees and employers, accustomed to autocracy, to the benefits of a more democratic workplace.

4. Since some subjects were Afrikaans-speakers, the questionnaire was also translated into Afrikaans, and translated back into English to ensure standardization of the items.

5. 'QC participation' is a dichotomous variable indicating membership in either group. ' $Q C$ membership' denotes which quality circle the subjects were drawn from, in order to test for between-circle effects. The order of introduction of variables into the equation was rotated in order to test all possible permutations. The results in Table 4 present the data from the best fit.

\section{References}

Bachman, J., Kahn, R., Davidson, R. \& Johnston, L. 1967. Youth in transition - volume 1. Ann Arbor, Michigan: Institute for Social Research.

Barrick, M.R. \& Alexander, R.A. 1987. 'A review of quality circle efficacy and the existence of positive-findings bias', Personnel Psychology, Vol. 40: 579-592.

Beardsley, J. 1987. 'Beyond whatever is left', Journal for Quality and Participation. Vol. 10: 28-30.

Biesheuvel, S. 1984. Work motivation and compensation. Volume 1: Motivational aspects. Johannesburg: McGraw-Hill.

Bocker, H.J. \& Overgaard, H.O. 1982. 'Structuring quality circles: A management challenge to combat ailing productivity', Leadership and Organizational Development Journal, Vol. 3: 17-29.

Castorina, P. \& Wood, B. 1988. 'Circles in the Fortune 500: Why circles fail', Jownal for Quality and Participation, Vol. 11: 40-41.

Chang, R.H., \& Dodder, R.A. 1983. 'The modified purpose-inlife scale: A cross-national validation study', International Journal of Aging and Human Development, Vol. 18: 207-217.

Clemmer, J. \& McNeil, A. 1988. 'Team leadership: Two plus two can equal six', Canadian Manager. Vol. 13: 11-13.

Cotgrove, S. 1972. 'Alienation: Its meaning and measurement', The British Journal of Sociology, Vol. 23: 437-451.

Cotton, J.L., Vollrath. D.A. \& Froggath, K.L. 1988. 'Employee participation: diverse forms and different outcomes', Academy of Management Review, Vol. 13: 8-22.
Cotton, J.L., Vollrath, D.A., Legnick-Hall, M.L. \& Froggath K.L. 1990. 'Fact: the form of participation does matter - a rebuttal to Leana, Locke, and Schweiger', Academy of Management Review, Vol. 15: 137-159.

Cox, J. \& Dale, B.G. 1985. 'Quality circles members' views on quality circles', Leadership and Organizational Development Journal, Vol. 6: 20-23.

Crumbaugh, J. 1968. 'Cross-validation of purpose-in-life test based on Frankl's concepts', Journal of Individual Psychology, Vol. 24: 74-81.

Dale, B.G. \& Hayward, S.G. 1984. 'Some of the reasons for quality circle failure: Part 3', Leadership, Vol. 5: 27-32.

Daniel, R. \& Huss, A. 1986. 'Add to your quality circles', Productivity, Vol. 12: 32-33.

Davis, L.E. \& Wacker, G.J. 1982. 'Job design'. In Salvendy, G. (Ed.). Handbook of industrial engineering. (pp. 131). New York, NY: John Wiley.

Denhardt, R.B. 1971. 'Alienation and the challenge of participation', Personnel Administration, Vol. 34: 25-32.

Drago, R. 1985. 'Are quality circles a fad? A look at some new evidence', The Quality Circles Journal, Vol. 81: 12-17.

Drago, R. 1988. 'Quality circle survival: an exploratory analysis. Industrial Relations, Vol. 27: 336-351.

Elvins, J.P. 1985. 'Communication in quality circles: members' perceptions of their participation and its effects on related organizational communication variables', Group and Organizational Studies, Vol. 10: 479-507.

Frank, J.P. 1973. 'Can workers still feel a sense of accomplishment?', Management Review, Vol. 62: 56-58.

Fuller, M.M. \& Bonjean, C.M. 1970. 'Self-fulfilling work and social integration: a comparative study. In Sociological $A b$. stracts, abstract no. E2686.

Garvin, D.A. 1988. Managing quality. New York, NY: Free Press.

Gelfand, J.S. 1975. The effect of an intervention process on organizational climate. University of the Witwatersrand, Johannesburg. Unpublished Ph.D. thesis.

Gibson, P. 1982. Work in America institute studies in productivity, No. 26: Quality circles: An approach to productivity improvement. New York, NY: Pergammon Press.

Griffin, R.W. 1988. 'Consequences of quality circles in an industrial setting: a longitudinal assessment', Academy of Management Journal, Vol. 31: 338-358.

Guzzo, R.A. 1983. Work in America institute studies in productivity, No. 32: Programs for productivity and quality of work life. New York, NY: Pergammon Press.

Hackman, R.J. \& Lee, M.D. 1979. Work in America institute studies in productivity, No. 9: Redesigning Work: A Strategy for Change. Scarsdale, NY: Work in America Institute.

Ingle, S. 1982. 'How to avoid quality circle failure in your company', Training and Development Journal, 54-59.

JUSE. 1985. How to operate $Q C$ activities. Tokyo: Japanese Union of Scientists and Engineers.

Larson. J.S. 1989. 'Employee participation in federal management', Public Personnel Managemens, Vol. 18: 404-414.

Lawler, E.E. III \& Mohrman, S.A. 1987. 'Quality circles: after the honeymoon', Organizational Dynamics, Vol. 15: 42-54.

Leana, C.A., Locke, E.A. \& Schweiger, D.M. 1990. 'Fact and fiction in analyzing research on participative decision making: A critique of Cotton, Vollrath, and Froggatt', Academy of Management Review, Vol. 15: 137-146.

Likert, R. 1967. The human organization. New York, NY: McGraw-Hill.

Locke, E.A., Schweiger, D.M. \& Latham, G.P. 1986. 'Participation in decision-making: should it be used?', Organizational Dynamics, Vol. 14: 65-79. 
Marks, M.L., Hacketh, E.J., Mirvis, P.H. \& Grady, J.F., Jr. 1986. 'Employee participation in a quality circle program: impact on quality of work life. productivity, and absenteeism', Jound of Applied Psychology. Vol. 7: 61-69.

Miller. K.I. \& Monge. P.R. 1986. 'Participation, satisfaction and productivity: a meta-analytic review". Academy of Management Journal, Vol. 29: 727-753.

Miller, MJ. 1984. 'Quality circles today: a research note', Quality Circle Digest. Vol. 11: 28-30.

Neal, A. \& Seeman, M. 1964. 'Organizations and powerlessness: a test of the mediation hypothesis'. American Sociological Review, Vol. 24: 216-225.

Nicholls, A.D. 1985. Ford S.A. Employee involvement survey report. Port Elizabeth: SAMCOR.

Parroll, R. \& Hewill. J. 1978. 'Increasing self-esteem through participation in a goal-attainment program'. Journal of Clinical Psychology, Vol. 34: 955-957.

Rafaeli, A. 1985. 'Quality circles and employee relations', Personnel Psychology. Vol. 38: 603-615.

Rotter, J.B. 1966. 'Generalized expectancies for internal versus external control of reinforcement', Psychological Monographs, Vol. 80, (1, whole no. 609).

Scheips, C.D. 1972. 'The humanization of work'. Personnel, Vol. 49: 38-44.

Shepard, J.M. 1970. 'Functional specialization, alienation, and job satisfaction', Industrial and Labor Relations Review, Vol. 23: 207-219.

Sherwood, K.F., Guerrier, Y. \& Dale, B.G. 1985. 'Quality circles - can we evaluate them?', Personnel Review, Vol. 14: 26-31.

Spreitzer, E.A., Snyder, E.E. \& Larson, D.L. 1981. Occupational variables as predictors of life satisfaction: some male-female differences. Additional abstracts of papers presented at the 1981 annual meeting of the 95 Eastern Sociological Society.

Steel, R.P. \& Lloyd, R.F. 1988. 'Cognitive, affective, and behavioral outcomes of participation in quality circles: conceptual and empirical findings', Journal of Applied Behavioral Science, Vol. 24: 1-17.
Swell R.P. \& Meana AJ. 1987. The perticipation performance

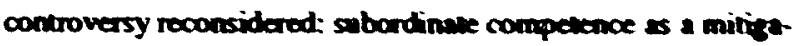
ing factor: Growp ond Ongmizerion Selies, Vol. 12 : $411-123$.

Sieel R.P. Mentea AJ. Dilla BJ_ Ovalle, N.K. \& Uoyd R.F. 1985. 'Factors influencing the success and failure of two quality circle programs". Journal of Memagement. Vol. 11: 99-119.

Sieel, R.P., Menta. A.J. A Reha V.R. 1985. 'Participant reactions to a quality cirde progran'. Queliny Circle Jownd. Vol. 8: 14-20.

Sreel, R.P. \& Shane, G.S. 1986. 'Evaluation research on quaticy circles: technical and analyuical implications: Humen Relar tions. Vol. 39. 449-465.

Strauss, G. 1974. 'Worker dissarisfuction: a look a the causes', Monhly Labor Review, Vol. 97: 57-58.

Susman, G.I. 1972. 'Automation, alienation, and work-group sutonomy', Human Relations, Vol. 25: 171-180.

Tang. T.L.P., Tollison. P.S. \& Whileside. H.D. 1989. 'Quality circle productivity as related to upper management attendance. circle initiation, and coller colox'. Jownal of Management. Vol. 15: 101-113.

Valecha, G.K. 1972. Construct validation of internal external locus of control as measured by an abbreviaed II-ikem IE scale. Ohio: Ohio State University. Unpublishod doctoral dissertation.

Wagner, J.A. III \& Cooding. R.Z. 1987. 'Effects of societal trends on participation research', Adminiserative Science Quarterly. Vol. 32. 241-262.

Watton, R.E. 1972. 'How to counter alienation in the plant'. Harvard Business Review, Vol. S0: 70-81.

Wayne, S.J., Griffin, R.W. Bateman, T.S. 1986. 'Improving the effectiveness of quality circles', Personnel Administrator. Vol. 931: 79-88.

Yamamoto, S. 1986. 'Tradition and management'. International Studies of Management and Organization. Vol. 15: 69-88. 